\title{
HISTORIOGRAFÍA Y FUENTES SOBRE LA DEUDA INTERNA NOVOHISPANA
}

\author{
Guillermina del Valle Pavón*
}

\begin{abstract}
A 1 igual que los Estados modernos, los de Antiguo Régimen requerían de capiA tales extraordinarios para cubrir sus faltantes, en especial durante las épocas de confrontación bélica. A fines del siglo XVIII y principios del XIX el imperio español se vio envuelto en varias guerras que se presentaron de manera sucesiva, las cuales ocasionaron a la real Hacienda metropolitana un déficit creciente que dio lugar a la demanda de numerosos empréstitos en Nueva España. Durante la guerra de Independencia la amenaza de los insurgentes y el bloqueo de caminos impidieron el flujo de los recursos del erario a la capital, por lo que la autoridad virreinal tuvo que valerse del crédito voluntario y forzoso para sostener sus campañas militares. Mientras, Agustín de Iturbide recurrió a la práctica colonial de requerir préstamos forzosos para superar la crisis de la Hacienda pública. En este contexto de continua demanda de capitales, el Tribunal del Consulado de México fungió como el principal intermediario financiero del erario novohispano y del gobierno de Iturbide en la obtención de los préstamos mencionados, papel que desempeñaron en menor medida los consulados de Vera cruz y Guadalajara, así como el Tribunal de Minería.

La corporación mercantil de la ciudad de México operó como instrumento del erario al captar los caudales de sus miembros, así como de los individuos y corporaciones acaudaladas que estaban vinculados con ellos. El poder del Consulado ante la autoridad virreinal, unido al crédito de sus dirigentes, dieron a los
\end{abstract}

* Instituto de Investigaciones Dr. José María Luis Mora. 
inversionistas la confianza necesaria para confiar a dicho cuerpo los capitales que serían canalizados a la real Hacienda, en lugar de colocarlos a rédito en corporaciones eclesiásticas o con comerciantes, invertirlos en bienes raíces o en alguna otra actividad económica como la minería.

Los empréstitos contraídos a través de los Tribunales de Comercio y Minería representaron la mayor parte de los compromisos gubernamentales de la colonia que se heredaron una vez realizada la independencia. En 1817 el erario novohispano reconocía una deuda activa que ascendía a poco más de 32000000 de pesos, de los cuales $41 \%$ correspondía a los débitos captados mediante el Tribunal de Comercio y $12 \%$ a los que Se habían obtenido a través del de Minería, mientras que la deuda generada a consecuencia de la consolidación de vales reales representaba $32 \%$. $^{1}$ Aun cuando se extrajo de la sociedad novohispana un volumen mucho mayor de caudales por concepto de los empréstitos mencionados, que a través de la consolidación, el interés de los historiadores por el estudio de ésta no puede compararse con el que han mostrado por los créditos que demandaron los gobiernos virreinales, posiblemente debido a que la mayor parte de los préstamos se otorgaron de manera voluntaria, por lo que no despertaron la oposición generalizada que suscitó la desamortización de los capitales eclesiásticos.

El hecho de que los caudales obtenidos a través de los empréstitos gubernamentales se hayan extraído de Nueva España para apoyar las campañas bélicas del imperio español, o se hayan perdido en la guerra contra los insurgentes, ubica dicho problema en el marco de la discusión sobre la profunda descapitalización de que fue objeto la economía mexicana a fines de la época colonial, y aporta elementos para comprender la forma en que el rico virreinato que a fines del siglo XVIII sostenía las posesiones españolas del Caribe y Filipinas, se transformó en la naciente república que tuvo que depender del crédito de los agiotistas para sobrevivir.

A pesar de la relevancia económica que tuvo la deuda generada mediante la contratación de los empréstitos adquiridos en las últimas décadas de la colonia, hasta ahora sólo contamos con dos artículos sobre el tema, el de Carlos Marichal acerca de los préstamos otorgados a la corona española entre 1781 y 1804 , en qué valora

1 "Sobre la deuda de la real Hacienda y medio de restablecer su crédito, México, 21 de febrero de 1817 ". B.N.Ma., ms. 19.702/23. Respecto a la forma en que la corona obtuvo recursos extraordinarios mediante la consolidación de vales reales véanse Romeo Flores Caballero, "La consolidación de vales reales en la economía, la sociedad y la política novohispanas", Historia Mexicana, vol. XVIII, núm. 3 (71), 1969, pp. 334-378; Brian Hamnett, "The appropriation of mexican Church wealth by the spanish bourbon government: the consolidación de vales reales, 1805-1809", Journal of Latin American Studies, vol. 1, núm. 2, 1969, pp. 85-113; Asunción Lavrín, "The execution of the law of consolidación in New Spain: economics aims and results", Hispanic American Historical Review, vol. 53, núm. 1, febrero 1973, pp. 27-49; Masae Sugawara, La deuda pública de España y la economía novohispana, 18041809, prólogo, bibliografía y selección de documentos, Instituto Nacional de Antropología e Historia, México, 1967 (Colección Científica 28), y "Los antecedentes coloniales de la deuda pública en México, 1) España: los vales reales, orígenes y desarrollo de 1784 a 1804", en Boletin del Archivo General de la Nación, 2a. serie, 8, núms. 1-2, 1976, pp. 
la presión ejercida sobre el conjunto de la población para extraer capitales y la importancia de la transferencia de fondos a la metrópoli.2 En otro se refiere al papel de las corporaciones religiosas en los préstamos negociados por el Consulado en 1782 y 1793, en él se presenta el contexto en que se efectuaron dichas demandas crediticias y se examina la racionalidad que guiaba las inversiones de las instituciones eclesiásticas, los mecanismos de que se valió el Tribunal mercantil para captar sus fondos y la relevancia que éstos tuvieron respecto al conjunto de los capitales negociados. ${ }^{3}$

Los trabajos sobre la real Hacienda novohispana han hecho referencia a la deuda interna que se contrajo a fines del periodo virreinal. Herbert Klein destacó el singular aumento que presentó la categoría préstamos e impuestos de emergencia en los ingresos del erario a partir de la década de $1780,{ }^{4}$ mientras que John Jay TePaske subrayó la tendencia de la real Hacienda a depender en forma creciente del crédito. ${ }^{5}$ Por su parte, Jan Bazant llamó la atención sobre la existencia de un importante mercado de capitales del que se benefició la metrópoli, cuando revisó los empréstitos contratados a fines de la colonia como el antecedente de la deuda extranjera que se contrajo luego de la consumación de la independencia. ${ }^{6}$

Otros autores han estudiado algunos de los empréstitos gubernamentales que se demandaron a raíz de la invasión napoleónica y la guerra de Independencia, sin embargo, sus trabajos revelan cierta confusión acerca del conjunto de los préstamos contratados en estas etapas, ${ }^{7}$ debido, tanto a las reiteradas demandas de capitales por parte del gobierno virreinal, como a la renegociación de los suplementos que formaban parte de los préstamos a corto plazo que no pudo cubrir la real Hacienda. Sobre los créditos que obtuvo el erario en los dos periodos mencionados se dispone de algunos documentos publicados, ${ }^{8}$ y respecto a los préstamos contra

2 Carlos Marichal, "Las guerras imperiales y los préstamos novohispanos, 1781-1804", Historia Mexicana, vol XXXIX, núm. 4, abril-junio 1990, pp. 881-907.

3 Guillermina del Valle Pavón, "Las corporaciones religiosas en los empréstitos negociados por el Consulado de México a fines del siglo XVIII", en Ma. del Pilar Martínez López-Cano (coord.), Iglesia, Estado y economia. Siglos XV1 al XIX, UNAM/1nstituto de Investigaciones Dr. José Ma. Luis Mora, México, 1995, pp. 225-239.

4 Herbert Klein, Las finanzas americanas del imperio español. 1680-1809, Instituto de Investigaciones Dr. José María Luis Mora/Universidad Autónoma Metropolitana-Iztapalapa, México, 1994, pp. 111-113.

5 John Jay TePaske, "La crisis financiera del virreinato de Nueva España a fines de la colonia", Secuencia Revista de historia y ciencias sociales, núm. 19, enero-abril 1991, pp. 126-130.

6 Jan Bazant, Historia de la deuda exterior de México (1823-1946), El Colegio de México, México, 1968, pp. 520.

7 Josefa Vega, "Los primeros préstamos de la guerra de Independencia, 1809-1812", Historia Mexicana, vol. XXXIX, núm. 4, abril-junio, 1990, pp. 909-932; Luis Jáuregui, "La anatomía del fisco colonial. La estructura administrativa de la real Hacienda novohispana 1786-1821 “, tesis de doctorado, Centro de Estudios Históricos-El Colegio de México, 1994; Cristina Gómez Álvarez, "Las arcas de la Iglesia al servicio de la guerra contrainsurgente: Puebla, 1810-1812", en Ma. del Pilar Martínez López-Cano (coord.), Iglesia, Estado y economia. Siglos XVI al XIX, Universidad Nacional Autónoma de México/Instituto de Investigaciones Dr. José María Luis Mora, México, 1995, pp. 269-272.

8 Juan E. Hernández y. Dávalos, Colección de documentos para la historia de la guerra de Independencia de México de 1808 a 1821, José María Sandoval Impresor, México, 1878, t. II. 
tados durante el gobierno de Agustín de Iturbide sólo he ubicado algunas referencias en la obra de Lucas Alamán. ${ }^{9}$

Por lo que toca a la historiografía española, sólo hace referencia a las medidas extraordinarias introducidas en las colonias para extraer mayores recursos, así como a los crecientes montos de metales que llegaban a la península procedentes de Indias. ${ }^{10}$ Únicamente Miguel Artola se refiere a los empréstitos negociados en América, cuando establece que representaron una proporción mínima respecto a la enorme deuda contraída en la península. ${ }^{11}$

En el estudio de la deuda interna que se contrajo en las últimas décadas del México colonial y durante el gobierno de Agustin de Iturbide, identificamos cuatro periodos que nos han permitido esclarecer el problema. En el primero, los Tribunales del Consulado y de Minería recibieron capitales a rédito de inversionistas que buscaban hacerlos redituar, a fin de contribuir al sostenimiento de las guerras que libró España contra Francia e Inglaterra entre 1779 y 1803. En la segunda etapa, correspondiente a los primeros años de la invasión napoleónica, los mercaderes que tomaron el poder en el Consulado luego de haber destituido al virrey José de Iturrigaray, otorgaron al erario varios préstamos a corto plazo con el objeto de que brindara auxilio a la metrópoli. En el tercer periodo, que cubre la guerra contra los insurgentes, las campañas realistas se financiaron mediante la obtención de caudales a crédito de manera voluntaria y forzosa, los cuales se consiguieron con el apoyo de los líderes del Consulado debido a su interés en reactivar el comercio y mantener el vínculo colonial. Y en el último periodo, que comprende el gobierno de Iturbide, la crisis de la Hacienda pública condujo nuevamente a la exigencia de préstamos forzosos, los cuales también se obtuvieron con la intervención del Tribunal Mercantil, en razón de la permanencia del régimen corporativo.

Además, existe otra etapa que antecede al periodo de los empréstitos que conformaron la deuda interna heredada por el México independiente, la cual abarca la primera mitad del siglo XVIII, en cuyas décadas la corona española negoció un conjunto de préstamos con el Consulado de la capital novohispana, como parte de los contratos de arrendamiento de la renta de alcabalas de la ciudad de México.

Respecto a las fuentes disponibles para abordar el estudio de la deuda novohispana, se dispone de instrumentos gubernamentales producidos por funcio-

9 Lucas Alamán, Historia de México desde los primeros movimientos que prepararon su independencia en el año de 1808 hasta la época presente. Instituto Cultural Helénico/Fondo de Cultura Económica, México, 1895, vol. 5 (Clásicos de la Historia de México)

10 José P. Merino Navarro, "Hacienda, deuda pública y desamortización con Carlos IV", Amiario de Estudios Americanos, separata del tomo XXXVIII, 1981, pp. 257-258; Pedro Tedde de Lorca "Política financiera y política comercial en el reinado de Carlos III", en Actas del Congreso Internacional "Carlos III y la Ilustración ", Siglo XXI, Madrid, 1990 , pp. $169,170,195$

11 Miguel Artola, La hacienda del Antiguo Régimen, Alianza Editorial/Banco de España, 1982, pp. 321-459. 
narios de la metrópoli y el virreinato, con materiales de carácter institucional elaborados por los ministros y empleados de los Consulados de comerciantes y el Tribunal de Minería, y con testimonios de naturaleza privada, los cuales representan una minoría respecto a los anteriores por tratarse en su mayoría de las solicitudes y reclamos de algunos acreedores. Dicho repertorio documental se concentra en varios acervos, sobre los cuales tratamos a continuación.

Sin lugar a dudas, el Archivo Histórico de Hacienda (AHH), que ahora forma parte del Archivo General de la Nación (en adelante AGN), constituye el repositorio documental más rico sobre el tema de la deuda interna novohispana, debido en gran medida a que el archivo del Consulado de comerciantes de la ciudad de México fue confiscado en septiembre de 1824, por el Ministerio de Hacienda de la Primera República Federal. ${ }^{12}$ De aquí, que la mayor parte de la documentación que existe en México sobre los empréstitos gubernamentales de los siglos XVII, XVIII y principios del XIX, se encuentre dispersa en el AHH, al cual se puede acceder mediante la consulta de un fichero, así como de las tres guías y el índice analítico que se han producido sobre su contenido. ${ }^{13}$

Otro acervo que contiene diversos testimonios sobre los empréstitos otorgados a la real Hacienda colonial, es el ramo Consulados del AGN ${ }^{14}$ En el Archivo Histórico de Hacienda y en el ramo Consulados se localiza información de naturaleza similar, sin embargo, únicamente en el segundo encontramos testimonios que reflejan algunas de las contradicciones que se produjeron entre el Tribunal Mercantil y las autoridades virreinales, como la correspondencia intercambiada entre el virrey, segundo conde de Revillagigedo, y los representantes del Consulado de la ciudad de México, cuando éstos se resistieron a conseguir capitales para el erario virreinal, debido a la actividad con que el virrey promovía las medidas librecambistas que perjudicaban directamente a los miembros de dicha corporación mercantil. Es posible que la ubicación de tales expedientes en el ramo Consulados se deba a que las autoridades del cuerpo mercantil no entregaron a la Hacienda pública todo el contenido de su archivo cuando éste fue confiscado.

12 Al respecto véase el "Inventario del Archivo de la contaduría y la Secretaria del Consulado, que éste entregó de acuerdo con la orden del ministro de Hacienda del 22 de septiembre de 1824", AGN, AHH, caja 267, exp. 22.

13 Agustín Hernández, Guía del AHH, Secretaria de Hacienda y Crédito Público, México, 1949; Esperanza Rodriguez de Lebrija, Índice analítico de la guia del Archivo Histórico de Hacienda, AGN/AHH, México, 1975 y Guía documental del Archivo Histórico de Hacienda, AGN, México, 1981; Marley David, Guía de la serie Archivo Histórico de Hacienda del AGN. México, Windsor, Ontario, Canadá, 1993 (mimeografiado).

14 Sobre el contenido y organización del ramo Consulados véase Pedro Pérez Herrero, "El ramo Consulado del Archivo General de la Nación", Boletín de Fuentes para la Historia Económica de México. Centro de Estudios Históricos de El Colegio de México, núm. 1, 1990, pp. 15-20. Además se cuenta con el Índice del ramo de Consulados, que se localiza en el mismo AGN y con el trabajo de Pedro Pérez Herrero, Ramo Consulados, AGN, México, 1982 (Serie Guías y Catálogos 29) 
Tanto en el Archivo Histórico de Hacienda como en el ramo Consulados del AGN, pueden hallarse, entre otros, los siguientes documentos: las reales cédulas sobre la imposición de capitales y la petición de empréstitos; las demandas de caudales a la corporación mercantil, las respuestas de su tribunal sobre los mecanismos más idóneos para obtener dinero a crédito, la autorización para imponer las rentas extraordinarias que solventaban el pago de réditos; los informes del Consulado respecto al avance en la recaudación de capitales; los textos de acuse de recibo de las cajas reales; los libros sobre el producto de los impuestos extraordinarios y el pago de réditos; las escrituras de "depósito irregular" a través de las cuales se tomaban capitales a rédito; las listas de quienes colocaron capitales para los diversos empréstitos; los registros sobre la restitución de capitales y la subrogación de escrituras, etcétera.

Es importante aclarar que en el Archivo Histórico de Hacienda y en el ramo Consulados, se encuentran los legajos sobre los empréstitos que solicitaron las autoridades virreinales, tanto al Consulado de la ciudad de México, como a los Tribunales de Minería y de los Consulados mercantiles de Veracruz y Guadalajara.

El ramo Préstamos y donativos, que forma parte del Fondo Secretaría de Cámara del AGN, también contiene una rica información sobre los créditos demandados en Nueva España a fines de la colonia. Éste es el único repositorio en el que hemos localizado material sobre los préstamos que recabó la real Hacienda de manera directa, es decir, sin la intermediación de alguna institución, así como testimonios sobre algunos de los empréstitos que se requirieron a través de los Tribunales de Minería y del Consulado de México.

En el ramo mencionado puede ubicarse información general sobre los préstamos gubernamentales de fines del virreinato, como los bandos referentes a su apertura; no obstante, la mayor parte del material contenido en esta sección del AGN es la correspondencia intercambiada entre las autoridades virreinales y algunos contribuyentes a los empréstitos, en la que éstos ofrecen la colocación de capitales, se excusan de colaborar con los suplementos, o reclaman la restitución de sus caudales, así como el pago de los réditos que éstos devengaban. Y cuando se trata de los créditos que fueron impuestos de manera forzosa, se hallan los escritos de los posibles colaboradores que piden ser exceptuados, que se reduzcan las cuotas que les fueron asignadas, o solicitan autorización para diferir el pago de las contribuciones a plazos o para saldar el monto asignado con los bienes que generaba la actividad productiva que realizaban.

La sección V del Archivo General de Indias, correspondiente al gobierno de la Audiencia de México, concentra la documentación de la real Hacienda y los consulados novohispanos, por lo que constituye otro importante repositorio documental sobre los empréstitos contratados por el erario colonial. En la serie relativa a la real Hacienda se localizan las disposiciones y consultas sobre los préstamos, las 
condiciones bajo las cuales se negociaron varios de ellos, así como los informes de los virreyes y del mismo Consulado acerca de la situación financiera de Nueva España y la dinámica que seguía la recolección de capitales.

Mientras que en los legajos referentes a los consulados del virreinato novohispano, se encuentra parte de la información que contienen los archivos de México, además de otros documentos que no se ubican en éstos, como los informes y dictámenes emitidos por el contador general del Consejo de Indias y el ministro de Finanzas respecto a diversos problemas, entre los que se destaca la administración del producto del derecho de avería extraordinaria, impuesto sobre el comercio exterior que se fue incrementando con los primeros créditos que contrajo la real Hacienda. Este material se refiere, entre otros aspectos, a las tensiones generadas en Nueva España por los intentos de normatividad administrativa que quiso imponer la Hacienda metropolitana a la corporación mercantil.

Por otra parte, se cuenta con algunas fuentes impresas como la Gazeta de México, en la que vienen los listados de los contribuyentes a los empréstitos que se recaudaron durante los periodos de la invasión napoleónica y la guerra contra los insurgentes. Es importante tener en cuenta que la información que contiene dicha publicación, ha dado lugar a confusiones debido a que no se precisan los préstamos a los que corresponden las mencionadas listas. ${ }^{15}$

Por último, las escasas fuentes que hemos localizado sobre los empréstitos demandados por el gobierno de Agustín de Iturbide, se encuentran en otros acervos documentales como son el Archivo de Relaciones Exteriores de México, el Centro de Estudios de Historia de México, Condumex, y el ramo Gobernación del AGN, en los cuales se hallan sumamente dispersas. 